\title{
INTERNATIONAL LEGAL LAWS FOR THE PROTECTION AND \\ REALIZATION OF RIGHTS OF PERSONS WITH \\ MENTAL DISORDERS
}

\author{
Sedžad Milanović ${ }^{1}$ \\ Elvira Sefer \\ Elvira Sefer
}

Governments of Middle Bosnia Canton

Received:12.06.2011

UDC: $347.161: 616.899$

Accepted:10.11.2011
342.7:364.65-056.36

\begin{abstract}
The legal regulation of the persons with mental disabilities their support primarily finds in international legal acts of which provisions each state by their free determination incorporate into their regulations and coordinate them with the national legal norms. The persons with the mental disabilities are the persons with some degree of mental retardation who in greater or lesser extent are not able to independently take care of the realization and protection of their rights. Bosnia and Herzegovina, though it is a signatory of a great number of the international legal acts for the protection of the persons with mental disabilities, contrary to the international modern standards, has a very few institutes in which are placed in the aforementioned persons, in order to be treated, rehabilitated and engaged in the social life.
\end{abstract}

Key words: protection, rights, persons with mental disorders

\section{TORICAL REVIEW}

The first written sources of mental patients we find in the Roman period and the data available suggest that up to then with this population treated using various inhuman methods of torture as a severe form of punishment or treatment. By establishing the first national communities comes to the development of medicine and within it means and forms of treatment, it is questionable whether such treatments have been applied toward the mentally ill. The position of the mentally ill in the Middle Ages remained backward and under the influence of the churches and Christian civilization, and which has led to a re-understanding that the mentally ill are possessed by the devil and demons. The treatments of these patients at this time again assumed primitive forms and mystical methods.

1 Correspodence to:

Sedžad Milanović, Governments of Middle Bosnia Canton, Ministry of Economy

Ul. Prnjavor 16a, Travnik, B\&H

Phone: +387 61479690

E-mail: sedzadmilanovic@ymail.com 
The mental state of the patients significantly improved only in the nineteenth century when it came to the development in psychiatry and when the mentally ill for the first time received hospital treatment.

The international acts regulating the rights of the persons with mental disorders have brought a variety of organizations, starting from 1948, until today.

The organizations that have adopted these acts, the United Nations with headquarters in New York, then the Council of Europe based in Strasbourg, the documents of the World Health Organization (WHO) of which the headquarters is in Geneva, Switzerland. These organizations commit the member states to respect the rights and fulfil their obligations under the provisions by their documents, and in case of violations of their provisions, the competent authority for dealing with complaints is the International Court for human rights in Strasburg. Bosnia and Herzegovina is a country that has adopted a number of international treaties by signing the Dayton Agreement for Bosnia and Herzegovina ${ }^{12}$ in such a manner that these international documents ratified by the Parliamentary Assembly, which became a part of internal legal order of Bosnia and Herzegovina, a legal force above the law. In the area of Bosnia and Herzegovina were adopted different legal acts regulating the rights of the persons with the mental disorders. It is the state and entity regulations, as well as the regulations made at the level of the District Brčko of $\mathrm{B} \& \mathrm{H}$, and the most significant are the Law on Prohibition of Discrimination of $\mathrm{B} \& \mathrm{H}$, Criminal laws as well as the Laws on criminal procedures at the level of $\mathrm{B} \& \mathrm{H}$, entities

2 The Dayton Peace Agreement (or more simple the Dayton Agreement or Dayton) is a legal act of consensual character initialled in the military airport Right-Paterson near Dayton, in the American state Ohio. The Agreement has determined the future administrative and constitutional order of $\mathrm{B} \& \mathrm{H}$. The Agreement was officially signed in Paris on 14 December 1995 and District Brčko B\&H, the Law on professional rehabilitation, training and employment of the persons with the disability of the FB\&H, as well as the Law on professional rehabilitation, training and employment of the disabled persons of the RS, the Laws on health care of the FB\&H and RS, the Law on Social Care of the District Brčko B\&H.

\section{DOCUMENTS OF THE UNITED NATIONS}

\subsection{Universal Declaration of Human Rights}

The Universal Declaration of Human Rights from 1948 concretizes the aim formulated in 1945 by the United Nations relating to the International Cooperation to solve economic, social, cultural and humanitarian problems as well as on fixing on human rights and fundamental freedoms regardless on race, sex, language or religion (Welti, 2005, p. 263).

The rights guaranteed by this Declaration are available to the persons who have a greater or lesser degree of mental disorder. Everyone needs to be provided by a standard of living adequate for the health and welfare, including food, clothing, housing, medical care, special social services, and the right to unemployment insurance, sickness, disability, widowhood, old age, or other lack of livelihood in the circumstances beyond his control (Turković, et. al, 2001, p. 5238). 


\subsection{International Covenant on Economic, Social and Cultural Rights}

This Covenant brought the United Nations on 19 December 1966 and ratified in $\mathrm{B} \& \mathrm{H}$ on

1 December 1993. Thorough the reporting and exchange of the member states this Covenant may have very much impact on the social state and a reliable mental disturbed person. In the practice, however, showed that this Covenant is not an instrument that could achieve a rapid implementation, and approaching to the fundamental provisions contained in the Covenant (Welti, 2005, p. 268). This Covenant has several articles that relate to the persons with mental disorders. Article 26 of the Covenant contains a provision according to which all are equal before the wall and are entitled to the protection given to them is guaranteed by law. It is forbidden to have any kind of discrimination on any basis. The Committee for economic, social and cultural rights has been entrusted to take care on implementation of the provisions of the International Covenant on economic, social and cultural rights. The Committee adopted the General Comment 5 from 1994.

\subsubsection{General Comment 5}

General Comment of the Committee for economic, social and cultural rights obliges the Member States to prohibit discrimination of the persons with disabilities (mental disorders) in the following areas: all equals for men and women (International Covenant on economic, social an cultural rights, Article 3), employment (International Covenant on economic, social an cultural rights, Article 6-8), social security (Article 9), family protection (Article 10 ), right to a standard of living for themselves and their families, health and welfare, including food, clothing, medical care and necessary social services, (Article 11), right on mental and spiritual health (Article 12), right on education (Article 13 and 14), and in the cultural life of community, freedom to participate in the scientific progress and in its benefit (http://www.hrea.org/).

\subsection{International Covenant on Civil and Political Rights}

This Covenant was adopted by the United Unions on 16 December 1966. It has no clear provisions for the protection of the persons with mental disorders. However, they can be subsumed under the term "other state" contained in Article 2 of the Covenant which prohibits discrimination based on the race or colour of skin or "other states".

\subsection{Convention of the United Nations on the Rights of the Child}

The Convention of the Rights of the Child in Article 23, paragraph 1 state: The member states recognize that a mentally retarded child should enjoy a full and decent life in conditions which ensure dignity, promote self-reliance and facilitate active participation of children in the community. ${ }^{3}$

The Committee on the Rights of the Child oversees the implementation of the Convention on the Rights of the Child.

The first report of the contracting state submits two years after adopting the Convention, and then periodically every five years.

3 Convention on the rights of the Child, United Nation Convention on the rights of the child, adopted and declared by the Resolution of the General Assembly No: 44/25 of 20 November 1989, date on entering into force: 2 September 1990. B\&H ratified this Convention 9 September 1993. 
In addition to four principles that should be followed while implementing the Convention (non-discrimination, best interests of the child, the right to life, survival and development of the child, the right of free expression) the Committee also drew attention on the other rights that are of particular importance for children with special needs: the right to know for their parents and the right to care, the right not to be separated from their parents unless a court decision when it is in the, best interests of children, right to protection from all forms of physical or mental violence, child's right to a standard of living, the right on social care, the right on health care, the right on education (Izmirlija, 2006, pp. 13-14). The interpretation of these provisions can be concluded that the mentally disturbed children as well as born healthy are accorded the same rights and protection of their rights, health, safety, and such protection is provided, since its birth (Convention of the United Nations on the Right of the Child, Article 3).

\subsection{Convention against torture and other cruel, inhuman or degrading punishments and procedures}

This Convention was adopted by the General Assembly Resolution on 10 December 1984, and $\mathrm{B} \& \mathrm{H}$ ratified it on 1 September 1993. The Convention defines the term torture and obliges the contacting states to take measures to prevent torture and other cruel, inhuman and degrading treatment and punishments. Unlike the notion of torture as defined in Article 1 of the Convention, cruel, inhuman and degrading treatment and punishment are not specifically defined. The Convention applies only to actions of the torture that often causes serious physical or mental disability, committed by officials or persons acting in an official capacity, but not to people from the private sector, especially given that many services, included services and support to people with special needs in the privatized world. For the purpose of monitoring the implementation of the Convention by the contracting state it was established the Committee against torture (Izmirlija, 2006, p. 17). The main request of this Convention is, therefore, to prevent torture, torture and other cruel, inhuman and degrading treatments by authorities. This Convention proclaims the specified protection for all persons, including those for the mentally disturbed.

\subsection{A set of principles for the protection of all persons in any form of detention or imprisonment}

A set of principles for the protection of all persons in any form of detention or imprisonment was adopted by the General Assembly on 9 December. ${ }^{4}$ The principles stipulate that the state measures are intended to protect, inter alia mentally disturbed persons shall not be deemed discriminatory, but justified because it is their purpose is intended to protect those persons with special needs and the rights and freedoms of persons with mental disabilities may be restricted by law, if it is in the interest of their safety and health.

4 Given the punishment of torture, inhuman and degrading treatment are not just historical occurrences, or something that viewed within the culture of certain countries, they have become an integral element of many contrasts and agreements, were they were observed without exception as a violation of human rights. In this connection the set of the minimum rights for the treatment of prisoners of 1955, Convention against the torture and other cruel, inhuman or degrading penalties and procedures from 1984, and a se $t$ of principles for the protection of all persons in any form of detention or imprisonment are the most important international acts in this field. Fr more see in Hilpert (2001, p. 193). 
No person who is in any form of detention or imprisonment shall be subjected to torture or to cruel, inhuman or degrading treatment or punishment (Hilpert, 2001). Any person detained or confined person must be offered a medical examination, medical treatment measures or when require medical reasons of a person deprived of liberty. In this way it is possible to determine his/ her health status and a level of mental development which may be important in determining criminal responsibility and sentencing.

\subsection{Declaration on the Rights of Persons with Mental Retardation}

Despite the fact that other international organizations seeking improvement of the status of the population they represent, in the framework of a special document of the UN a prevalent view is that people with mental disability are the most numerous group of people with difficulties, since they make up $3 \%$ of the population. The General Assembly has declared this Declaration with the statement that mentally disturbed people, to the highest degree of feasibility, enjoying the same rights as other people (Resolution of the General Assembly, 1971).

The Declaration contains the following rights: entitled to a maximum adjustments on the rights with other citizens, right to health care, entitled to such an upbringing, education, rehabilitation and counselling to mentally retarded allow maximum development of their ability, the right to economic security and adequate standard of living, as well as employment, and engagement in work, the right to live in your family/relatives, maximum participation in community, and exceptionally, if necessary, and placement in an institution which should be as close, to the family and normal life, entitled to qualified carers who will protect their interests, the right to protection from all forms of abuse of exploiting or degrading treatment, including judicial protection, if because of the weight of the handicap would be necessary to limit or delay some, right of a person with mental retardation, that person must be provided a maximum, of court protection, along with participation of an expert, and the right to appeal to the highest authorities (Teodorović, \& Bratković, 2001 , p. 280). Their rights can be limited only in the proceedings that must include the appropriate legal boundaries against every form of abuse, and with it, such decisions must be subject to the right of appeal and periodic testing (Radivojević, \& Bratković, 2007, p. 18).

\subsection{Declaration on the persons with disability}

According to this Declaration, the persons with disabilities are deemed as those who due mental or physical impairment, congenital or acquired, are not able to independently, partially or fully meets their needs that are common in personal and social life (Declaration on the rights of disabled persons, 1975). The Declaration emphasizes the rights of all disabled groups, or the degree of damage:

- respect for human dignity and the right on more and more normal and decent life;

- aid in training for a greater independence;

- complete medical, psychological and functional protection, supplies, rehabilitation, training and engaging in a normal life;

- economic and social safety, standards, employment and acting in the syndicates; 
- $\quad$ respecting their specific needs at all stages of the economic and social planning;

- life with own family and relatives, and participation in social life without any discrimination, and if necessary an accommodation in an institution, it should be as close as family life and the environment;

- protection of all forms of exploitation and humiliation;

- providing expert legal assistance to protect people and property;

- obligatory advising with the organizations of disabled persons in protection of their rights;

- right on permanent information of the disabled persons and their families on the rights form the Declaration (Teodorvić, B. \& Bratković, D., 2001, p. 281, Article 1).

\subsection{The principles of protection of persons with mental illnesses and mental health care}

These principles were adopted by the general assembly at its session held on 17 December 1991. the principles of protection of persons with mental illnesses and promotion of the mental health care establish minimal standards that are exclusively intended for the protection of the mentally ill persons. at the beginning of eh document it is emphasized that these persons are entitled on all available measures of the care regarding the mental health as and the right to treat with them humanly along with respecting human dignity. The other principles such as the rules on a way of determination of the existence of the mental disorder, treatment of the mental patients and others, govern the protection of persons with mental disorders. The principles stipulate that no one can compel to submit to medical examination in order to determine the presence or absence of the mental illness, except in accordance with the procedure established by the national laws. The patient has the right, whenever it is possible, to be treated in an institution near his/her home or homes of relatives or friends and has a right to return to the community as soon as possible. ${ }^{5}$

The principle of treatment determines that every patient is entitled to be treated in an environment that is at least possible measure restrictive, and the mental health should always be done in accordance with the applicable ethical standards of health care worker, including internationally accepted standards, such as the principles of the medical ethics adopted by the General Assembly of the United Nations.

A treatment can be carried out without the consent of the patient when treatment is urgent, when a patient has his/her an agent who is authorized by law to consent the treatment of the patient. The persons with mental illnesses ought to be informed and that as soon as possible after receipt and a language which a patient understands of all his/ her rights in accordance with these principles and national law, and information should also include the explanation of these rights and how they can be realized. Every patient in an institution for mental health has, particularly, the right on full respect: recognition everywhere as a person before the law; privacy, freedom of communication, freedom of religion or belief. ${ }^{6}$

5 The principles for the protection of persons with mental illnesses and improvement of the protection of the mental health, principle 7 .

6 Ibid., Principle 13. 
The principle 20 relates to the persons who serve their sentence of imprisonment for the criminal deeds or detained because of the criminal or investigation procedure, and for whom it was determined that they have a mental illness or it is believed that they have such illness. All such persons should have the best possible protection for the mental health (The principles for the protection of the persons with the metal illnesses and improving the protection of the mental health, 1991).

\subsection{The standard rules on the equalization of opportunities for the persons with disabilities}

By the Resolution 1990/26 of 24 May 1990 the ECOSOC UN has authorized the Commission for social development to make a framework of rules on formation equal possibilities for the mentally retarded children, youth and adults in close cooperation with the special organizations, nongovernmental organizations, especially organizations for the disability persons. After this, at the beginning of 1991, the Commissions for social development adopts the Resolution $32 / 2$ by which she decided in line with the ECOSOC-Resolution in purpose of this to found an open all-state ad-hoc working group. With the Resolution A/Rea/48/96 of 20 December 1993 the General Assembly of the United Nations adopts the Standard Rules that were a symbol of the then prevailing opinion regarding the rights of the persons with disabilities. Still today, this instrument is among the most important in international law for the protection of the disabled persons. The Standard Rules on equalizing the possibilities for the persons with disabilities consist of four parts: the target areas, equal participation, measures for implementation and control mechanisms.
On occasion of this they cite the Universal Declaration on Human Rights from 1948 as its political and moral background. In compliance with the point 15 of the introduction of the Standard Rules the justifiableness of this instrument lies in the fact that that the persons with disabilities as the participants of the community has the same rights and obligations as the other co-citizens. At the same time it was emphasized that this is not about how it is wrongly interpreted, that they grant special rights, but that the already existing rights apply without differences (Rothfritz, L., P., 2010, pp. 44-45).

The first part, "Preconditions of the equal participation" mostly covers the rules on the different forms of the support to the persons with disabilities, such as the medical care, rehabilitation, services and equipment that should decrease functional limits and increase the independence of the persons with the disabilities.

The second part that bears the title" The target fields of the human participation" regulates the ways on which the states ought to enable realization of certain rights of the persons with disabilities.

The third part, under the title the "Implementation measures" contains a range of the obligations for the states that should lead to as complete realization of the rights of the disabled persons. The Standard Rules seek from the states to establish national coordination committees that should serve them as focusing point for all issues of the disability (The Standard Rules on equalizing the possibilities for the persons with disabilities, 1993, rule 17.)

In the special fourth part of the Standard Rules it was regulated a mechanisms with a view of promotion and later implementation of the rules contained in this documents. The Commission for the social development has a task for monitoring of these rules, and it was also foreseen appointing a Special reporter for the issues of the disability (Radivojević, Z., \& Raičević, pp. 20-21). 


\section{THE DOCUMENTS OF THE COUNCIL OF EUROPE}

\subsection{The European Convention on protection of the human rights and fundamental freedoms}

This Convention is important because it is the only document on human rights that establishes institutions that care about the implementation of its provisions to allow citizens who feel victimized in their rights by the state to submit the individual lawsuit to these institutions to protect the rights of the injured people (Hilpert, 2001, p. 194).

The protocol 12 along with the Convention on protection of the human rights and fundamental freedoms stipulates a prohibition of discrimination on any basis, for example, sex, race, colour of skin, language, religion, political and other belief, national or social origin, old age, connection with national minority, property, birth or other status. ${ }^{?}$

\subsection{Recommendations}

Among other documents of the Council of Europe an important place takes the Recommendation 818 from 1977 which deals with the position of the mentally ill persons which invites the governments of the member states top ensure the greatest possible rights of the patients with mental retardation, then the Recommendation R (83) 2 (1983), which is in connection with the legal protection of the mentally ill persons forcibly placed into the institute the Recommendation No $\mathrm{R}$ (90) that relates to the medical investigations on the human beings and the Recommendation

7 The European Convention on Protection of the Human Rights was adopted on 4 November 1950. Protocol No 2 along with Convention on Protection of the Human Rights and Fundamental Freedoms, Article 1.
1235 (1994) that deals with the psychiatrics and human rights. The said Recommendation tells about a procedure and conditions of receiving the patients, their treatment ${ }^{8}$, problems and abuses in psychiatrics $^{9}$ and the position of the detained persons (Recommendation 12 35, 1994).

\section{THE DOCUMENTS OF THE WORLD HEALTH ORGANIZATION (WHO)}

Within the framework of the World Health Organization $^{10}$ the most important instruments are the fundamental principles for the protection of the mental health were made in Geneva in 1996:

- promotion of the mental health and prevention of the mental disorders;

- approach to the fundamental protection of $h$ mental health;

- estimations of the mental health in compliance with the internationally recognized principles and standards,

- insurance of the least restrictive form of the protection of the mental health;

- self-determination;

- the right on the assistance on a occasion of self-determination;

8 Lobotomies and therapies with electroshocks can not be carried out except a patient, person, advisor or a guardian chosen by the patient as his/her agent did not give an informal consent in writing. Furthermore, it is foreseen that must be correct and detailed evidence of the treatment of the patient, applicable medical staff, the patients must have a free approach the advisor who is independent of the institute, and it is also necessary to establish a system of inspection.

9 This rule implies that a code of ethics must explicitly prescribe that the therapists must not have sexual contacts with the patients. Using the cells for isolation should be strictly limited. It should not be used any mechanical limitation of the move, and the scientific investigation in the field of the mental health must not be undertaken without the knowledge of the patient or against his/her will or the will of his/her agent and must be carried out only in the interest of the patient.

$10 \mathrm{~B} \& \mathrm{H}$ has been the member of this Organization since 1992. 
- availability of the review and evaluation.

- The system of the periodic controls and evaluations;

- Qualified decision-maker;

- Respect for the rule of law (Mental health care: Ten basic principles, 2010).

\section{THE DOCUMENTS OF THE WORLD MEDICAL ASSOCIATION}

\subsection{The Declaration on ethical issues in dealing with patients who suffer from mental illnesses}

This Declaration contains the provisions on the rules of dealing with the patients who suffer from the mental illnesses. It is necessary to eradiate discrimination that is being connected with the psychiatrics and mental patients. The psychiatrist should aspire to establishing a psychiatric relation based on the mutual confidence. He/she is obliged to inform the patient with a nature of his/her illness, therapies and expected outcome. A patient with mental illnesses should also enjoy the same treatment like any other patient who is temporary or permanently incapacitated. ${ }^{11}$ This Declaration stipulates that the treatment without consent may be carried out only if a patient is in an acute condition and presents a threat for him/her and others.

The duty of the psychiatrist is to offer the best available therapy according to his/her knowledge and treat with a patient carefully and respectfully. The Declaration stipulates that one should respect the confidentiality and secrecy of personal data and must never be misused official position to the detriment of the patient.

11 Declaration on ethical issues in treating with the patients, who suffer from the mental illnesses, World Medical Association, September 1995.

\subsection{Madrid Declaration}

The Madrid Declaration from 1996 emphasises the importance of the relation psychiatrist - patient and the ethical standards and rules of behaviour towards the treated. The psychiatrists should be lead by own responsibility for the recovery of the patients, enabling them applicable treatment and respecting their personality. In order to achieve the purpose of the treatment it is necessary to include a patient into the process of healing, to establish a relation based on confidentiality and mutual respecting, to offer a patient information how he/she could participate, in line with his/her condition, in making decisions that concern him/her. When he/she is not able to make such decisions, the psychiatrist may contact his/her family or a legal representative, placing in the first plan the interest of the patient. This relates to a psychiatrist who is qualified, skilled and capable to perform his/her duty respecting their personality. To achieve the purpose of treatment it is necessary to involve the patient in the healing process, to establish a relationship based on trust and mutual respect, provide patient information that he/she could take part, in line with his/her status in making decisions that concern him/her. When a patient is not able to make such decisions, the psychiatrist may contact his/her family or a legal representative, placing in the first plan the interest of a patient. This relates to a psychiatrist who is qualified, skilled and capable to perform his/her duties. Information that a psychiatrist learns during the treatment should keep as a secret and use it only exceptionally, for the purpose of promotion of the patient's mental health or prevention of the serious damage not only to the patient, but also to a third person. 


\section{REFERENCES}

- Convention on the rights of the Child, United Nation Convention on the rights of the child, adopted and declared by the Resolution of the General Assembly No: 44/25 of 20 November 1989, date on entering into force: 2 September 1990.

- Declaration on the rights of disabled persons, proclaimed by GA Res. 3447 (XXX) of 9 December 1975.

- Hilpert, K. (2001). Menschenrechte und Theologe Forschungsbeitragäge zur ethischen Dimension der Menschenrechte, Saint-Paul, Universitäsverlag Freiburg, Schweiz,

- http://www.hrea.org/ taken over on 28 March 2011.

- Izmirlija, M. (2006). Ljudska prava osoba s invaliditetom, situacija u BiH, Srbiji i Crnoj Gori [The human rights of the persons with disability, situation in B\&H, Serbia and Montenegro]. Centar za ljudska prava Univerziteta u Sarajevu, B\&H.

- Mental health care: Ten basic principles, http:// www,who.int/mental health, taken over on 15 October 2010.

- Radivojević, B. \& Bratković, D. (2007). Međunarodna zaštita osoba $\mathrm{s}$ duševnim poremećajem [International protection of the people with mental disturbance], Viktimološko društvo Srbija, No 3, Belgrade, Serbia.

- Rothfritz, L., P. (2010). Die Konvention der Vereinten Nationem zum Schutz der Rechte von Menschen mit Behiderrungen: Eine ANlyse unte Bezgnahme auf die deutsche und europaische Rechtsebene, Peter Lang, Frankfurt am Main.

- Recommendation 818, adopted by the General Assembly on 8 October 1977.
- Recommendation No $R$ (83) 2 in connection with the legal protection of the mentally ill persons forcibly placed into the institute, adopted by the Committee of Ministers on 22 February 1983 at $356^{\text {th }}$ session.

- Recommendation 1235 from 1994.

- Resolution of the General Assembly 2856, XXVI9 of 20 December 1971.

- Teodorović, B. \& Bratković, D. (2001). Osobe s teškoćama u razvoju u sustavu socijalne skrbi, [People with disabilities in the social welfare], Education and Rehabilitation Faculty of the University in Zagreb, Croatia.

- The principles for the protection of the persons with the metal illnesses and improving the protection of the mental health, (1991). http://www.psihijatrija.com, taken over on 15 October 2010.

- The Standard Rules on equalizing the possibilities for the persons with disabilities, A/Res/48/96 of 20 Turković et. al (2001). The Law on Protection of Persons with Mental Disorders, a comment with enclosures, School of Law of the University in Zagreb, Psychiatric Hospital Vrapče, Zagreb, Croatia.

- December 1993, rule 17.

- The European Convention on Protection of the Human Rights was adopted on 4 November 1950. Protocol No 2 along with Convention on Protection of the Human Rights and Fundamental Freedoms, Article 1.

- Welti, F. (2005). Behinderung und Rehabilitation in socialzen Rechtsstaat: Freiheit, Gleichheit und Teilhabe behinderter Menschen, Mohr Siebeck.

- World Medical Association (1995). Declaration on ethical issues in treating with the patients, who suffer from the mental illnesses. 